\title{
Analysis of the Determinants of Diabetes Mellitus in Indonesia: A Case Study of the 2014 Indonesian Family Life Survey
}

\author{
Fariza Zahra Kamilah*, Farhan Habibie, Gina Ridhia Rahma, Mohammad Naufal Faisal \\ Sofyan, Nurma Sari Isnaini, Nurul Dita Nadhilah, Estro Dariatno Sihaloho \\ Faculty of Economics and Business, Padjadjaran University, Bandung, Jawa Barat, \\ Indonesia
}

*corresponding author, e-mail: fariza17002@mail.unpad.ac.id

Received: 08/11/2020; published: 24/08/2021

\begin{abstract}
Background: Diabetes mellitus (DM) is a disease of excessive blood sugar levels. Data from the Indonesian Ministry of Health shows that several DM survivors have had DM for over 15 years reached 19.98 million or $10.9 \%$ of the Indonesian population in 2019 with population data according to the Central Bureau of Statistics Republic of Indonesia. This research aimed to determine factors affecting DM in Indonesia. Method: This was a study with a crosssectional design. The data used in this study came from the fifth wave of the Indonesian Family Life Survey (IFLS). A total of 34,257 individuals aged 14 or over as samples. The dependent variable was diabetes mellitus, while independent variables were obesity, hypertension, quality of sleep, and socio-economic factors. The data measurement was performed by logistic regression. Results: The research found that obesity, hypertension, and poor sleep quality will increase the risk of DM and also the risk will increase due to socioeconomic factors like age, education, household income, urban, and marital status. Conclusion: This study found that the driving force for DM in Indonesia is obesity, hypertension, and sleep quality.
\end{abstract}

Keywords: diabetes mellitus; obesity; hypertension; quality of sleep; Indonesia

This is an open-access article under the CC-BY-SA license.

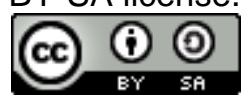

\section{Introduction}

Diabetes Mellitus (DM) is a disease that occurs as a result of excessive levels of sugar in the blood (hyperglycemia) in response to the inability of the pancreas to produce insulin [1]. When the pancreas cannot produce insulin, the body will have difficulty maintaining blood sugar levels, leading to excess sugar levels or hyperglycemia. Diabetes mellitus is divided into diabetes mellitus type I and diabetes mellitus type II [2]. Type I diabetes mellitus occurs when the body is unable to produce insulin, while type II diabetes mellitus occurs when the body is unable to receive and process insulin effectively. This second type will lead to obesity and a lack of physical activity.

According to a report from the International Diabetes Federation (IDF), in 2019, people $>20$ years old with diabetes mellitus worldwide reached 463 million people or $9.3 \%$ of the world's population [3]. The death rate caused by diabetes reaches 4.6 million people. In Asia and Australia (West Pacific), the number of people with diabetes mellitus aged 20 years has reached 162.6 million people or equivalent to $9.6 \%$ of the entire population in Southeast Asia with 1.2 million deaths. Meanwhile, Indonesia is the 6th highest ranked country with cases of people with diabetes mellitus aged 15 years and over with a prevalence of $10.9 \%$ [4]. The prevalence of diabetes mellitus in Indonesia based on the doctor's diagnosis for age 15 is $2 \%$. There was an increase of $1.5 \%$ compared to the prevalence of diabetes mellitus in Indonesia in 2013. DKI Jakarta, East Kalimantan, DI Yogyakarta, North Sulawesi, and East Java were the top five provinces with the highest diabetes mellitus cases in Indonesia [5]. 
Factors that can increase a person's diabetes mellitus are related to an unhealthy lifestyle, such as irregular eating patterns, lack of activity, obesity, to hypertension [6]. According to previous research, gender affects a person's risk of developing Diabetes Mellitus, where women have a more significant potential to develop diabetes mellitus than men [7]. In other studies, gender affects a person's diabetes. Women are most susceptible to type 2 DM because premenstrual syndrome, postmenopausal, and pregnancy increasing body mass index (BMI) and insulin resistance [8]. Lifestyle is one of the critical factors in increasing the risk of diabetes, one of which is an increase in the pattern of life in urban areas due to urbanization's influence, which causes unhealthy eating patterns and causes obesity, which has a six-fold risk of developing diabetes [9]. Diabetes can reduce the productivity of sufferers because a person gets tired quickly. It can harm the country's economy because it increases the cost of treatment and medical costs due to the increase in the price of insulin analog one [4].

Other factors are obesity, age ( $\geq 45$ years), female gender, lack of physical activity, and hypertension, risk factors for increasing diabetes mellitus cases [10]. This case is reinforced by research that the older a person is, the changes in carbohydrate metabolism and insulin release are affected by blood glucose [11]. In addition, someone who suffers from type 2 diabetes without controlled treatment can trigger complications such as macroangiopathy, which caused changes in blood pressure due to complications in large blood vessels, and this is due to increased blood sugar sticking to the walls of blood vessels [12].

This case is supported by the inadequate condition of the health sector in developing countries, both in terms of human resources and facilities, so that the diagnosis of people with diabetes is not well controlled [13]. Sleep quality is also one of the factors in increasing the risk of developing diabetes mellitus. Individuals who have poor sleep quality, one of which can be seen from the length of sleep that is less than 7-8 hours and more than 7-8 hours per day, will increase blood sugar (HbA1c), lead to insomnia, increase insulin resistance and ultimately potentially lead to diabetes $[14,15]$.

According to the World Health Organization (WHO), the cause of type $1 \mathrm{DM}$ is unknown and cannot be prevented with current knowledge. However, simple healthy lifestyles such as maintaining food intake, doing activities, and exercising are pretty effective in preventing or delaying the onset of diabetes. It is also essential to take preventive measures such as checking for DM through regular, random, and fasting blood glucose tests, glycated hemoglobin (HbA1c) tests, and blood pressure control. This study was conducted to determine the probability of diabetes caused by age, education, BMI, hypertension, sleep quality, and several socio-economic factors as independent variables.

\section{Method}

The method used in this study was a quantitative method with a cross-sectional design. The data source was from the Indonesia Family Life Survey (IFLS) 5, representing individuals and households in Indonesia in 2014. The population in this study was 34,257 people, with IFLS 5 respondents who answered the module on health conditions and chronic diseases. The research sample amounted to 29,786 people with inclusion criteria, which respondents were willing to answer questions related to diabetes status in the IFLS 52014 health and chronic disease module. The independent variables in this study were hypertension disease status, BMI, and sleep quality (deficient, adequate, or good). In addition, the individual characteristic variables; age (15-64 years), gender, socio-economic factors, the status of area of residence, marital status, and education level. Data were analyzed multivariate with logistic regression with marginal effects using Stata 14. .

\section{Results and Discussion}

\subsection{Results}

3.1.1. Respondents Characteristics

Of the 29,786 respondents, some respondents had diabetes $(2.15 \%)$ and hypertension (11.66\%). Most of the respondents are women (53.34\%), aged 21-50 years $(66.56 \%)$, live in urban areas $(58.71 \%)$, and a married $(80.21 \%)$. Respondents had adequate sleep quality (53.53\%) and normal nutritional status (40.39\%). The average income of respondents in the study represented by per capita income is Rp. 1,142,968,00 per month. 
Tabel 1. Respondents Characteristics

\begin{tabular}{|c|c|c|}
\hline Variabel & $\mathbf{n}$ & $\%$ \\
\hline \multicolumn{3}{|l|}{ Diabetes } \\
\hline Yes & 641 & 2.15 \\
\hline No & 29,145 & 97.85 \\
\hline \multicolumn{3}{|l|}{ Hipertension } \\
\hline Yes & 3,474 & 11.66 \\
\hline No & 26,312 & 88.34 \\
\hline \multicolumn{3}{|l|}{ Gender } \\
\hline Male & 13,899 & 46.66 \\
\hline Female & 15,887 & 53.34 \\
\hline \multicolumn{3}{|l|}{ Age } \\
\hline$<20$ years old & 4,047 & 11.59 \\
\hline $21-50$ years old & 19,825 & 66.56 \\
\hline$>50$ years old & 6,914 & 19.85 \\
\hline \multicolumn{3}{|l|}{ Living Area } \\
\hline Urban & 17,486 & 58.71 \\
\hline Rural & 12,300 & 41.29 \\
\hline \multicolumn{3}{|l|}{ Marital Status } \\
\hline Married & 23,890 & 80.21 \\
\hline Not married & 5,896 & 19.79 \\
\hline \multicolumn{3}{|l|}{ Education Level } \\
\hline Not going to school & 1,193 & 4.01 \\
\hline Elementary school & 8,885 & 29.83 \\
\hline Junior high school & 5,844 & 19.62 \\
\hline Senior high school & 9,882 & 33.18 \\
\hline University & 3,982 & 13.37 \\
\hline \multicolumn{3}{|l|}{ Sleep Quality } \\
\hline Deficient & 3,456 & 11.60 \\
\hline Adequate & 15,945 & 53.53 \\
\hline Good & 10,385 & 34.87 \\
\hline \multicolumn{3}{|l|}{ BMl } \\
\hline Underweight & 3,746 & 12.58 \\
\hline Normal & 12,031 & 40.39 \\
\hline Overweight & 4,469 & 15.00 \\
\hline Obesity level 1 & 7,029 & 23.60 \\
\hline Obesity level 2 & 2,511 & 8.43 \\
\hline
\end{tabular}

3.1.2. Multivariat Analysis Results

Table 2 shows the results of the variables of hypertension $(95 \% \mathrm{Cl}=0.004-0.013$; $\mathrm{p}<0.05)$, age $(95 \% \mathrm{Cl}=0.001-0.001 ; \mathrm{p}<0.05)$, urban residence $(95 \% \mathrm{Cl}=0.007-0.015$; $p<0.05)$, married $(95 \% \mathrm{Cl}=0.013-0.038 ; \mathrm{p}<0.05)$, education level $(95 \% \mathrm{Cl}=0.002-0.013$; $0.000-0.013 ; 0.003-0.015 ; 0.007-0.022 ; p<0.05)$, per capita expenditure $(\mathrm{Cl} 95 \%=0.005-$ $0.011 ; p<0.05)$, and nutritional status $(95 \% \mathrm{Cl}=0.003-0.013 ; 0.011-0.022 ; 0.013-0.023$; $0.009-0.021 ; p<0.05)$, positively related to the incidence of DM. While the variable of adequate sleep quality was negatively related to the incidence of $\mathrm{DM}(95 \% \mathrm{Cl}=-0.014-(-$ $0.003) ; p<0.05)$. 
Tabel 2. Multivariate Analysis Results

\begin{tabular}{lcccc}
\hline \multicolumn{1}{c}{ Variables } & $\begin{array}{c}\text { Marginal } \\
\text { Coefficient } \\
\text { (dx/dy) }\end{array}$ & $\begin{array}{c}\text { Standard } \\
\text { Error }\end{array}$ & P value & Cl 95\% \\
\hline Hipertension & 0.023 & 0.002 & 0.000 & $0.004-0.013$ \\
Gender & 0.003 & 0.002 & 0.118 & $-0.001-0.006$ \\
Age & 0.001 & 7.290 & 0.000 & $0.001-0.001$ \\
Living Area (Urban) & 0.011 & 0.002 & 0.000 & $0.007-0.015$ \\
Marital Status (Menikah) & 0.026 & 0.006 & 0.000 & $0.013-0.038$ \\
Income & 0.007 & 0.001 & 0.000 & $0.005-0.011$ \\
Sleep Quality & & & & \\
$\quad$ Adequate & -0.009 & 0.003 & 0.004 & $-0.014-(-0.003)$ \\
$\quad$ Good & -0.008 & 0.003 & 0.110 & $-0.014-(-0.002)$ \\
BMI $\quad$ & & & \\
$\quad$ Normal & 0.008 & 0.002 & 0.000 & $0.003-0.013$ \\
$\quad$ Overweight & 0.016 & 0.003 & 0.000 & $0.011-0.022$ \\
$\quad$ Obesity level 1 & 0.018 & 0.003 & 0.000 & $0.013-0.023$ \\
$\quad$ Obesity level 2 & 0.015 & 0.003 & 0.000 & $0.009-0.021$ \\
Education Level & & & & \\
$\quad$ Elementary school & 0.007 & 0.003 & 0.006 & $0.002-0.013$ \\
$\quad$ Junior high school & 0.006 & 0.003 & 0.046 & $0.000-0.013$ \\
$\quad$ Senior high school & 0.009 & 0.003 & 0.003 & $0.003-0.015$ \\
$\quad$ University & 0.014 & 0.004 & 0.000 & $0.007-0.022$ \\
$\quad$ & & & & \\
$\quad$
\end{tabular}

\subsection{Discussion}

Someone who has bad behavior in maintaining their health increases the risk of developing diabetes [16]. Based on the study results, a person's probability of developing diabetes increases with the individual's age $(0.1 \%)$. A similar study previously conducted in Spain in 2018 showed that both men and women at an older age had more diabetes cases. The prevalence of someone experiencing obesity is also higher over time, where obesity is a risk factor for diabetes [17].

Based on the results of the study, hypertension showed a positive and significant relationship to diabetes. A person can be said to have hypertension if the blood pressure measured using a sphygmomanometer shows a systolic of $140 \mathrm{mmHg}$ or a diastolic of 91 $\mathrm{mmHg}$. If blood pressure exceeds these criteria, it can cause insulin resistance which triggers hyperinsulinemia. If not treated, it will cause Impaired Glucose Tolerance (TGT) which causes damage to pancreatic beta cells, resulting in type 2 diabetes [18]. The regression results carried out in this study also found that individuals who suffer from hypertension have a $2.3 \%$ higher probability of developing diabetes than those who do not suffer from hypertension. Another study using 5-year IFLS data stated that an increase in body fat in obese people with type 2 diabetes would have a harmful effect on hypertension, with a prevalence value of 1.3 times, so obese people with type 2 diabetes are more likely to suffer from hypertension [19].

$\mathrm{BMI}$ is a measurement that considers weight and height to classify an adult's body weight as too low, normal, overweight, or already obese. An increase in BMI will increase the risk of diseases, one of which is diabetes [20]. When an individual is at the highest BMI level, the individual is classified as obese, and people with excess weight or obesity tend to have insulin resistance. Insulin resistance causes an increase in fatty acids in plasma, which impacts decreasing glucose transport into muscle cells and increasing fat breakdown, which in turn causes an increase in liver glucose production. Insulin resistance also causes hyperinsulinemia which will cause diabetes [21]. The results showed a positive and significant relationship between BMI and diabetes. The higher the BMI level, the higher the probability of the individual developing diabetes. According to BMI calculations, individuals included in the obesity criteria 1 and 2 have a higher probability of developing 
diabetes by $1.8 \%$ and $1.5 \%$ compared to individuals with the criteria of individuals who have too low body weight.

Then, the results showed that the place of residence had a positive and significant influence on the prevalence of diabetes. Someone who lives in an urban area has a $1.13 \%$ higher probability of developing diabetes than someone in a rural area. Urbanization can affect the prevalence of diabetes because the urban environment is considered potentially obesogenic and diabetogenic [22]. Urbanization can also encourage changes in a person's lifestyle. Another study also explained that people living in urban areas have a higher risk of obesity, increasing the risk probability of type 2 diabetes [23].

Based on the study results, married people would have a $2.6 \%$ higher chance of developing diabetes than not married people. The number of married women respondents influenced this. The results of another study stated that married women tend to be obese due to an indifferent attitude to changes in body weight [24]. Moreover, during pregnancy, glucose needs tend to increase and affect the work of the hormone insulin, which causes high blood glucose, although, after delivery, it will return to normal glucose, the potential to transfer DM II can occur in later life [25].

The following study results showed the significance of the level of education on the incidence of DM. The regression results indicate that the higher the education level of an individual (especially high school and university/equivalent), the higher the probability of that individual suffering from diabetes. Another study found that individuals who have a high level of education have a higher risk of obesity [23]. Another study also stated that individuals with higher education tend to be passive smokers, which also increases the risk of suffering from diabetes [26].

Income is a wage or salary obtained from completing a job by someone both during work and outside working hours (overtime). A person's income is one of the factors that a person has diabetes. High income can increase the opportunity to consume excessive food, causing obesity [27]. This condition is in line with the results of this study which stated that an increase in income (per capita expenditure) would increase a person's probability of developing diabetes by $0.7 \%$. In addition to excessive food consumption, a high-income level will trigger a person to have an unhealthy lifestyle, especially in alcohol consumption [28]. Another study found that people with lower incomes tend to have a lower risk of developing diabetes than people with higher incomes [29]. This risk is due to changes in people's lifestyles in an unhealthy direction. People with high-income levels tend to have low physical activity [30]. People tend to eat food according to taste and eventually leave a balanced diet [31].

As the implementing agency implementing the health insurance program, the Health Insurance Administration Agency has started running the Chronic Disease Management Program or Program Pengelolaan Penyakit Kronis (Prolanis). Prolanis is a health program that focuses on managing patients with type 2 DM and hypertension. In general, 54.3 percent of the Prolanis participants have benefited from this activity [32]. However, the implementation of Prolanis has not been optimal until now. Because the number of sufferers often exceeds Prolanis health workers, lack of training for Prolanis health workers, lack of budget for Prolanis activities, and the absence of written Service Operational Standards regarding Prolanis activities [33-35]. The same thing also happened to a more community-based government program, the Integrated NonCommunicable Disease Development Post (Posbindu PTM), which is still not widely used by the community $[36,37]$.

\section{Conclussion}

Based on the research results from IFLS data in 2014, it can be concluded that Indonesian people with a history of hypertension, obesity, and poor sleep quality have a higher tendency to suffer from DM. Moreover, age, marital status, residency area, whether in a suburban or rural area, level of education, and income also affect the likelihood of developing diabetes mellitus risk.

Build upon the study results, researchers recommend establishing more health services that can facilitate the community in checking DM through blood tests, the need for family supervision to change lifestyles to become healthier, provide counseling about the prevention and risk of DM, and hold physical activity activities for the community. Such as 
healthy exercise together. In addition, Puskesmas also need to provide more effective services, especially in preventive, promotive, and educative programs, to improve the community's health status around the Puskesmas.

\section{Referensi}

1. Kurniawaty E, Yanita B. Faktor-Faktor yang Berhubungan dengan Kejadian Diabetes Melitus Tipe II. Med J Lampung Univ. 2016;5(2):27-31. Available from: https://juke.kedokteran.unila.ac.id/index.php/majority/article/view/1073

2. Hartati I, Pranata AD, Rahmatullah MR. Hubungan Self Care Dengan Kualitas Hidup Pasien Diabetes Melitus di Poli Penyakit Dalam RSUD Langsa. JP2K. 2019;2(2):94104. Available from: http://stikescnd.ac.id/jurnal/index.php/smart/article/view/30

3. International Diabetes Federation. Diabetes Atlas. 9th ed. 2019.

4. Kemenkes. Hari Diabetes Sedunia Tahun 2018. Jakarta: Kementerian Kesehatan RI; 2019.

5. Kementerian Kesehatan RI. Infodatin Diabetes Mellitus. Pusat Data dan Informasi Kementerian Kesehatan RI. 2020;4.

6. Verdiana NN, Nurjana MA. Hubungan Perilaku Konsumsi dan Aktivitas Fisik dengan Diabetes Mellitus di Indonesia. Bul Penelit Kesehat. 2019;47(2):97-106. doi: https://doi.org/10.22435/bpk.v47i2.667

7. Fadilah NA, Saraswati LD, Adi MS. Gambaran Karakteristik dan Faktor-Faktor yang Berhubungan Dengan Kejadian Diabetes Melitus Tipe 2 Pada Wanita (Studi di RSUD Kardinah Kota Tegal). J Kesehat Masy. 2016;4(1):176-83. Available from: https://ejournal3.undip.ac.id/index.php/jkm/article/view/11772

8. Wahyuni KI, Prayitno AA, Wibowo YI. Efektivitas Edukasi Pasien Diabetes Mellitus Tipe 2 Terhadap Pengetahuan dan Kontrol Glikemik Rawat Jalan di RS Anwar Medika. J Pharmascience. 2019;06(01):1-9. doi: http://dx.doi.org/10.20527/jps.v6i1.6069

9. Lathifah NL. Hubungan Durasi Penyakit dan Kadar Gula Darah dengan Keluhan Subyektif Penderita Diabetes Melitus. J Berk Epidemiol. 2017;5(2):231-9. doi: https://doi.org/10.33482/medika.v7i1.119

10. Asmarani, Tahir AC, Adryani A. Analisis Faktor Risiko Obesitas dan Hipertensi dengan Kejadian Diabetes Melitus Tipe 2 di Rumah Sakit Umum Daerah Kota Kendari. J MEDULA. 2017;4(2):322-31. doi: http://dx.doi.org/10.46496/medula.v4i2.2807

11. Isnaini N. Faktor Risiko Mempengaruhi Kejadian Diabetes Mellitus Tipe Dua Risk Factors was Affects of Diabetes Mellitus Type 2. J Keperawatan dan Kebidanan Aisyiyah. 2018;14(1):59-68. doi: http://dx.doi.org/10.31101/jkk.550

12. Winta AE, Setiyorini E, Wulandari NA. Hubungan Kadar Gula Darah Dengan Tekanan Darah Pada Lansia Penderita Diabetes Tipe 2. J Ners dan Kebidanan. 2018;5(2):16371. doi: https://doi.org/10.26699/jnk.v5i2.ART.p163-171

13. Misra A, Gopalan H, Jayawardena R, Hills AP, Soares M, Reza-Albarrán AA, et al. Diabetes in Developing Countries. J Diabetes. 2019;11(7):522-39. doi: https://doi.org/10.1111/1753-0407.12913

14. Brouwer A, van Raalte DH, Rutters F, Elders PJM, Snoek FJ, Beekman ATF, et al. Sleep and $\mathrm{HbA1C}$ in Patients With Type 2 Diabetes: Which Sleep Characteristics Matter Most? Diabetes Care. 2019 Nov;2-9. doi: https://doi.org/10.1007/s11892-020-01324-w

15. Parmar M. Obesity and Type 2 Diabetes Mellitus. Integr Obes Diabetes. 2018 Jan;4 (4). doi: http://dx.doi.org/10.15761/IOD.1000217

16. Poulsen K, Andersen LL, Poulsen K, Andersen LL. Linking Data on Work, Health and Lifestyle to Explain Socio-Occupational Inequality in Danish Register-Based Incidence of Diabetes. Scand J Public Health. 2016;44(4):361-8. doi: https://doi.org/10.1177/1403494816629533

17. Basterra-gortari FJ, Bes-rastrollo M, Ruiz-canela M, Gea A, Sayón-orea C, Martínezgonzález MÁ. Trends of Obesity Prevalence Among Spanish Adults with Diabetes, 1987-2012. Med Clin (Barc). 2018;152(5):181-4. doi: https://doi.org/10.1016/j.medcli.2016.11.022

18. Wang H, Lu Y, Yan Y, Tian S, Zheng D, Leng D, et al. Promising Treatment for Type 2 Diabetes: Fecal Microbiota Transplantation Reverses Insulin Resistance and Impaired Islets. Front Cell Infect Microbiol. 2020;9(January):1-10. doi: https://doi.org/10.3389/fcimb.2019.00455 
19. Mei C, Ronoatmodjo S. Hubungan Diabetes Melitus dengan Hipertensi pada Populasi Obesitas di Indonesia ( Analisis Data IFLS-5 Tahun 2014 ) Relationship between Diabetes Mellitus and Hypertension in Obesity Populations in Indonesia ( Data Analysis Of IFLS-5 in 2014 ). J Epidemoilogi Kesehat Indones. 2019;3(1):19-24. Available from: http://journal.fkm.ui.ac.id/epid/article/view/3164

20. WHO. Fact Sheet: Obesity and Overweight. 2020. Available from: https://www.who.int/news-room/fact-sheets/detail/obesity-and-overweight (Diakses pada 24 April 2021)

21. Al-Goblan AS, Al-Alfi MA, Khan MZ. Mechanism Linking Diabetes Mellitus and Obesity. Diabetes Metab Syndr Obes. 2014;7:587-91. doi: https://doi.org/10.2147/dmso.s67400

22. Gassasse Z, Smith D, Finer S, Gallo V. Association Between Urbanisation and Type 2 Diabetes: An Ecological Study. BMJ Glob Heal. 2017;2(4):1-8. doi:10.1136/ bmjgh2017-000473

23. Rachmi CN, Li M, Baur LA. Overweight and Obesity in Indonesia: Prevalence and Risk Factors D A Literature Review. 2017;7. doi: https://doi.org/10.1016/j.puhe.2017.02.002

24. Liberty IA. Hubungan Obesitas dengan Kejadian Prediabetes pada Wanita Usia Produktif. J Kedokt dan Kesehat. 2016;3(2):108-13. Available from: https://ejournal.unsri.ac.id/index.php/jkk/article/view/5161

25. Rana M, Hossain G. Factors Influencing in Developing Type II Diabetes among Married Women in Bangladesh: Data from Bangladesh Demographic and Health Survey 2011. J Life Sci Life Sci. 2019;11(1-2):17-24. doi: 10.31901/24566306.2019/11.12.241

26. Kim J, Noh J, Choi J, Park E. Association of Education and Smoking Status on Risk of Diabetes Mellitus: A Population-Based Nationwide Cross-Sectional Study. Int J Environ Res Public Health. 2017;14(6):1-9. doi: https://doi.org/10.3390/ijerph14060655

27. Song L, Shen L, Li H, Liu B, Zheng X, Zhang L, et al. Socio-Economic Status and Risk of Gestational Diabetes Mellitus Among Chinese Women. Diabet Med. 2017;34(10):14217. doi: https://doi.org/10.1111/dme.13415

28. Yen H, Li C, Hsia P. A Segment of Healthy and Unhealthy Lifestyle Consumers Affects Healthcare Expenditures: An Application of Data Mining in Healthcare. Int J Futur Comput Commun. 2017;6(3):86-91. doi: http://dx.doi.org/10.18178/ijfcc.2017.6.3.495

29. Ulfa A, Purwanti OS. Pengaruh Self Instructional Training Terhadap Efikasi Diri Pada Penyandang Diabetes Melitus. Semin Nas Keperawatan Univ Muhammadiyah Surakarta. 2020;25-33. doi: http://hdl.handle.net/11617/11907

30. Wu H, Caroline A, Wild SH, Jian W, Dong J. Socioeconomic Status and Self-Reported, Screen-Detected and Total Diabetes Prevalence in Chinese Men and Women in 20112012: A Nationwide Cross-Sectional Study. J Glob Health. 2018;8(2). doi: https://doi.org/10.7189/jogh.08.020501

31. Wiastuti SM, Widayati N. The Effect of Diabetes Self-Management Education and Support [ DSME / S ] on Stress in Patients with Type 2 Diabetes Mellitus in the Area of Public Health Center of Patrang Jember. e-Jurnal Pustaka Kesehat. 2017;5(2). Available from: https://jurnal.unej.ac.id/index.php/JPK/article/view/5784

32. Ariana R, Sari CWM, Kurniawan T. Perception of Prolanis Participants About Chronic Disease Management Program Activities (PROLANIS) in the Primary Health Service Universitas Padjadjaran. NurseLine J. 2019;4(2):103. doi:10.19184/nlj.v4i2.12687

33. Rosdiana AI, Raharjo BB, Indarjo S. Implementasi Program Pengelolaan Penyakit Kronis (Prolanis). Higeia J Public Heal Res Dev. 2017;1(3):140-50. Available from: https://journal.unnes.ac.id/sju/index.php/higeia/article/view/14617

34. Rachmawati S, Prihhastuti-Puspitasari H, Zairina E. The Implementation of A Chronic Disease Management Program (Prolanis) in Indonesia: A literature review. J Basic Clin Physiol Pharmacol. 2020;30(6):1-6. doi: https://doi.org/10.1515/jbcpp-2019-0350

35. Ramsar U, Trisnantoro L, Putri LP. Implementasi Program Pengelolaan Penyakit Kronis (Prolanis) di Puskesmas Poasia Kota Kendari. Vol. 6, Jurnal Kebijakan Kesehatan Indonesia : JKKI. 2017. p. 200-3. doi: https://doi.org/10.22146/jkki.v6i4.26899

36. Rahadjeng E, Nurhotimah E. Evaluasi Pelaksanaan Posbindu Penyakit Tidak Menular (Posbindu Ptm) Di Lingkungan Tempat Tinggal. J Ekol Kesehat. 2020;19(2):134-47. doi: https://doi.org/10.22435/jek.v19i2.3653

37. Sari DWR, Savitri M. Faktor-Faktor yang berhubungan dengan Pemanfaatan 
Disease Prevention and Public Health Journal

ISSN:2720-9997

POSBINDU Penyakit Tidak Menular (PTM) di Wilayah Kerja PUSKESMAS Kecamatan Setia Budi Kota Jakarta Selatan Tahun 2018. J Kebijak Kesehat Indones JKKI. 2018;7(2):49-56. doi: https://doi.org/10.22146/jkki.36849 